\title{
Analysis of Small Holes Manufacturing for Optomechanical Components
}

Jan Podaný, Jan Tomíček

Faculty of Mechanical Engineering, CTU in Prague. Technická 1902/4, 16000 Praha 6. Czech Republic. E-mail: Jan.Podany@fs.cvut.cz, Jan.Tomicek@fs.cvut.cz

Small holes can be manufactured by several ways. It is important to define in what dimensions the small holes vary. Anyway, drilling is one of the oldest technologies of holes manufacturing. In small dimensions we use the term microdrilling for description. Beside this conventional way of manufacture there are also unconventional methods. Microdrilling bits very often break before they are worn. Therefore, the tool life of these bits its quite unexpectable. It is due to relatively high load against the drill bit strength. So, it is important to choose proper drill bit material, cutting geometry, construction, process liquid, clamping and cutting conditions. These parameters are import for achieving ideal conditions for microdrilling. Even a tiny change in pre-seted parameters can lead to destruction of these delicate tools. Fiber arrays are designed and manufactured for precise positioning of optical fibers in row (1D) or in plate (2D). Fiber arrays can contain most of fibers including polarization maintaining fibers (PMF).

Keywords: microdrilling, microdrilling bit, optomechanics, fiber array

1 Conventional and unconventional methods of small holes machining

Small holes can be manufactured by many ways. It is important to define in what dimensions the small holes vary. Anyway, drilling is one of the oldest technologies of small holes manufacturing. Beside the conventional ways of manufacturing there are also unconventional methods. Review of technologies is in table bellow (Tab.1.).

Tab. 1Technology review

\begin{tabular}{|l|l|}
\hline Conventional methods: & Unconventional meth- \\
Spiral micro drill bit & ods: \\
Spade micro drill bit & Laser \\
D shaped micro drill & Electron beam \\
bit & Ultrasonic vibrations \\
One flute micro drill & EDM \\
bit & ECM \\
Step mricro drill bit & SACE \\
Coated micro drill bit & \\
\hline
\end{tabular}

1.1 Conventional technology - micro drilling

Drilling is type of chip forming process where blind or throughcoming holes of given diameter in different materails are made. For drilling we use drill bits tools and drilling machines as machine tools.

Microdrilling comes out from simple drilling and is different in the size of drilled holes. There is no given limit value but generaly we cab say that machining of holes $1 \mathrm{~mm}$ in diameter and smaller is consideret as microdrilling. Companies define the holes diameter by themsleves.

Term „microdrilling“ was introduced as result of task where the hole size was in few mikrometers. Exact definition of microdrilling relates to diameter with no specific size. Each manufacturer and researcher definec hole diameter different way with no specific standard. For example, Small hole drilling company declares their ability to microdrill holes from $0.03 \mathrm{~mm}$ up to $2.99 \mathrm{~mm}$ with precision of placing and depth of drilled hole $\pm 0.01 \mathrm{~mm}$. The Rotana company presents diameters from $0.1 \mathrm{~mm}$ up to $3 \mathrm{~mm}$. Zheng and co. States that micro drill bit diameter varies from 0.03 $\mathrm{mm}$ up to $1 \mathrm{~mm}$. In these cases, we can see, that the definiton is different for every company and resercher. Therefore, it is good to keep the common definition to prevent ambiquity between many opinions. Based on many studies we can say that microdrilling is drilling where the hole diameter is smaller or equal to 1 $\mathrm{mm}[1]$.

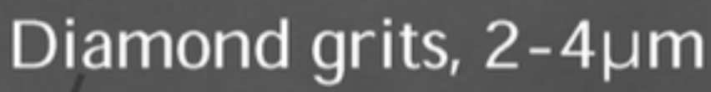

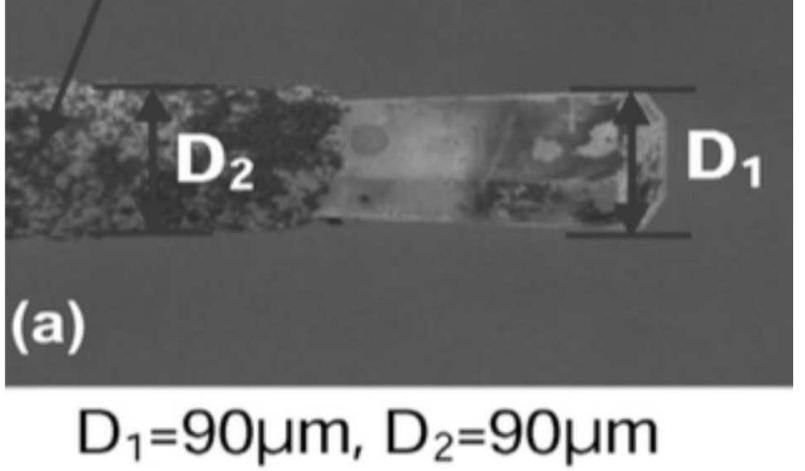

Fig. 1 Combinatory microdrilling bit with diamond coating 


\subsection{Unconventional technologies}

Advantage of laser beam - as one of unconventional methods - are mainly in its applicability on wide area of materials that are not possible to manufacture with other methods or it is difficult to do so. Materials like glass, ceramics, polymers or kevlar and carbon composites. [3,27]

Basic characteristic properties of laser beam are the coherence, monochronomaticity and low divergency of beam. These properties allow us to focus the laser beam into small point and archieve high areal energy density (up to $10^{8} \mathrm{~W} \cdot \mathrm{cm}^{-2}$ ) that is important for part machining. [5,28]

Most often used types of lasers for drilling and microdrilling are solid-state Nd-YAG and Yb-YAG lasers or neodymium-doped $(\mathrm{Nd})$ or Ytterbium-doped (Yb) yttrium aluminum garnet laser. Both are slowly replaced by $\mathrm{CO} 2$ lasers with same efectivity but smaler heat affected area. The wavelength of these lasers is around $1060 \mathrm{~nm}$ with a minimum drilled hole diameter of $0.1 \mathrm{~mm}$ and an accuracy of $0.001 \mathrm{~mm}$. [4]

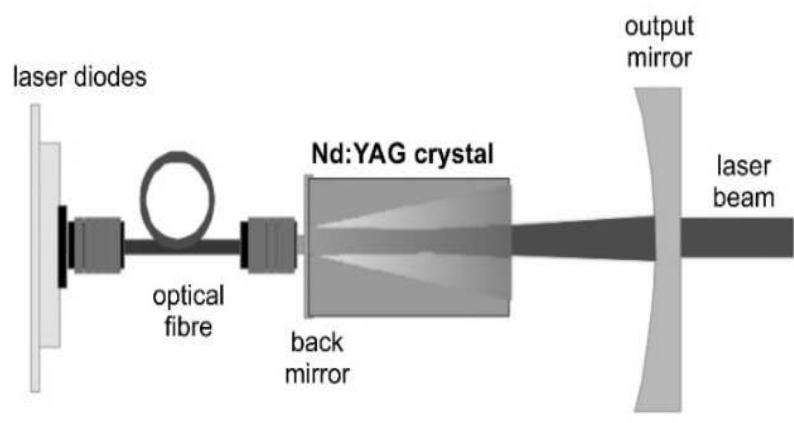

Fig. 2 Diagram of a solid-state Nd:YAG laser [6]

For microholes is currently available for example the technology of microEDM (electroerosive machining), laser, mechanical drilling etc. Among these technologie the EDM i sone of the most effective unconventional technologies. It is a non-contact process, suitable for machining very hard and very strong materials, so calle HRSA materials (otherwise considered to be „Difficult to cut" materials). With this method we can create both holes and dificult 3D shapes. In this method electric discharges are created that are moving between the tool (one electrode) and conductive workpiece material (other electrode) that is submerged into dielectric liquid. Heat that is created with sparks allows melting and evaporating the workpiece material and eroding the electrode [7].

As allready written it is a very effective method for drilling of deep holes but extensive use in mass production is currently not possible. The main reason is the unstable nature of this process, control of fragments removal, tool wear and low material removal rate. The main disadvantage of this processs is the tool wear that is caused by high heat that leads to increase of cost of manufacturing. On the contrary the advantage is the ability to make complex shapes with high precision, lack of mechanical forces and deformations. For characterization of output of this process from the erosion speed point of view we use the so called Material removal rate (MRR). For the reason of above stated disadvatages is necessary to precisely select the working condition for efective working process. Among the factors that influence the efectivity belongs i.e.:

- Process parameters (voltage, current, pulses)

- Type of dielectric liquid

- Tool properties

- Material properties $[7,8]$

For that reason experimental research is made in order to improve the EDM process. For example it wass discovered that the thermal properties of workpiece material affect the quality and precision of holes. In this experiment was compared sintered carbide (WC-Co) and stainless steel (SUS 304). Properties like low thermal conductivity, high disposition to quenching and high duktility under increased temperature are lowering the quality of drilling and dimensional stability by their unstable process (lower the MRR). [7]

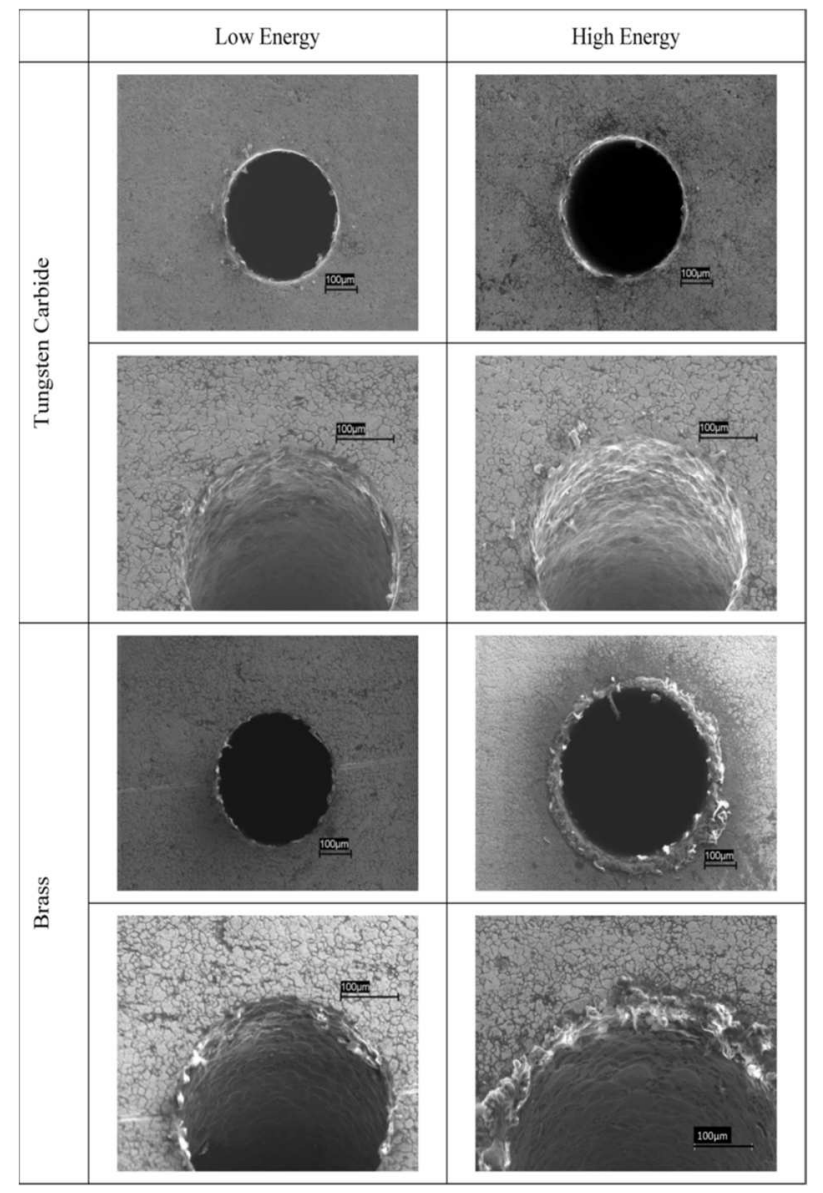

Fig. 3 Micro-drillend holes for different energies and electrodes [7] 
Technology of drilling with use of electron beam uses kinetic energy of the stream of accelerated electrons. The essence of this method is transformation of kinetic energy from the the electrons that hit the surface into thermal energy leading to melting of surface. Material is evaporating from surface and continually deepening hole is sreated. Beam penetrates the surface and stops in certain depth. Generated thermal energy concentrates under surface and causes the eruptive evaporation of material.

Vapours from evaporated material are ionized and cause new focusation in the place of impact. Characteristic feature of this metod is significant ration between width and depth of hole.

Working mode is contact of electron beam with surface of workpiece. We recognize continual or pulse work mode. Exact drilling is archieved with use of the pulse mode where the pulse time is from $2 \mu$ s to 0.01 s with pulse frequency 500 to $10000 \mathrm{~Hz}$. $[9,10]$

Electron beam is often used for microdrilling. Minimum hole diameter is stated to be $0.015 \mathrm{~mm}$. Such thin holes are drilled with high speed and it is possible to make up to 4000 holes per second. At deep hole drilling with ratio of length to diameter up to 100 it is necessary to use the beam with diameter $2 \mathrm{x}$ up to $4 \mathrm{x}$ smaller in comparision to drilled hole diameter. Tollerance of the drilled hole diameter is from 5 to $20 \%$ of its diameter. [10]
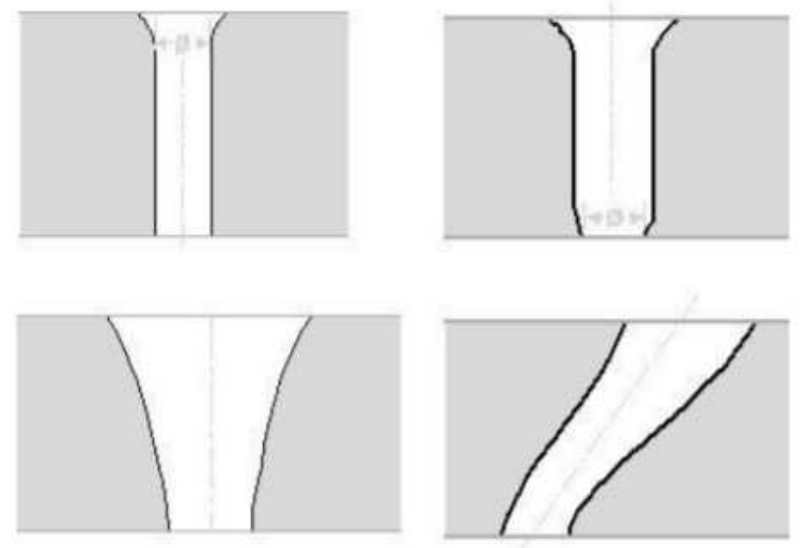

Fig. 4 Profiles of holes made with the "drill on fly" method [13]

The ,drill on fly "method is using the electron beam and it exact bending against the workpiece. If the beam during one pusle is focused on the same place of impact it will create the hole with round diameter. Change will happen with changing place of impact by using relative movement between the laser beam and machined workpiece. In this case we archieve a nonrotational hole. With this method we can create complex shape surfaces in holes. [11,12]

Source of electrons is autoemission or thermoemission. Autoemission sources are emiting electron from cathode due to action of strong electric field.
Disadvantage of autoemission is need of ultra vakuum thats causing mora abundant use of thermoemission. At thermoemission the electron beam is generated from surface of cathode heated to high temperature. The so called ,electron gun" is formed by heated tungsten cathode and anode. Electrons emited from cathode are accelerated with appropriate anode to the speed equal to $2 / 3$ of the speed of light.

Generated electron beam must be focused to the smallest possible area to increase the energy density. Focusation is made with use of electromagnetic lenses. The resulting energy density is approximatelly $10^{8}$ $\mathrm{W} \cdot \mathrm{cm}^{-2} \cdot[10,11]$

Electrochemical machining (ECM) is a method of chipless machining of materials that are electrically conductive. This method is using the knowledge of impact of electrci current to electrolyte. The principle is based on the physical phenomenon called electrolysis. Electrochemical machining is further connected with Faraday's laws, termodynamics of galvanic cells and theory of electrolytes. [14]

The workipecce connected as anode is merged into the electrolyte. With closed circuit we get a reaction where the cations of electrolyte are reacting with anions of metal and thus removing the metal from anode. Tool (cathode) is copying the shape of the wanted product.

The removal rate depends on several factors:

- Smallest possible gap between the electrodes and keeping it at constant value for the whole time (cca 0.05 to $1 \mathrm{~mm}$ )

- Temperatue

- Flow rate

- Electrolyte structure (typical using $\mathrm{NaCl}$, $\mathrm{NaNO}_{3}, \mathrm{HCl}, \mathrm{NaOH}$ )

Materials that are consideted to be badly machinable with the electromechanical machining are the alloys with higher contect of carbon, dural alloys with silicon and grey ćast iron that is almost unmachinable.

Holes with diameter smaller then $1 \mathrm{~mm}$ in materials that are difficult to machine are possible to manufacture with following methods of electrochemical machining:

- Electrolytical drilling with shaped tube (STEM $=$ Shaped Tube Electrolytic Machining)

- $\quad$ Fine electrolytical drilling $(\mathrm{ECF}=$ Electrochemical Fine drilling)

- Electrolytical drilling with a focused stream of electrolyte (ESD = Electro-stream drilling) [13] 
Ultrasound supported technology is ideal for machining of hard and brittle materials. This process is workiing efectivelly if the hardness of machined materials is higher then 40 HRC. [15]

Principle of ultrasonic machining is based on moving the tip of tool with ultrasonic vibrations and on dosing the abrasive suspenstion into the machining area. Abrasive particles in the machining area are getting the energy with ultrasonic oscilation along their axis. Oscilating tool is forcing the abrasive particles to hit the machined surface in the gap between the tool and the workpiece and to machine the work area. At the ultrasonic machining the material is removed in the form of microparticles that are formed with radial and lateral microcracks. $[15,16]$

Researchers in studies [17],[18],[19] described three basic mechanisms of material removal - mechanical abrasion as result of:

- Direct embossing of big abrasive particles percusiion efect

- Impact efect of smaller free moving abrasive particles in gaps created by biger abrasive particles (called the ,working gap")

- Cavitionally erosive efect where the gas buble is colapsing in the working gap by absorbing the energy of ultrasonic vibrations

This process is used mainly for cutting and machining. In present many scientists are working on use of this technology also to manufacturing of micrholes. At ultrasonic microdrilling ale used the ultrasonic vibrations with frequency higher than $20 \mathrm{kHz}$ to oscilate the tool or workpiece. Figture 5 (a) is showing the tyFigal diagram of ultrasonic microdrilling process.

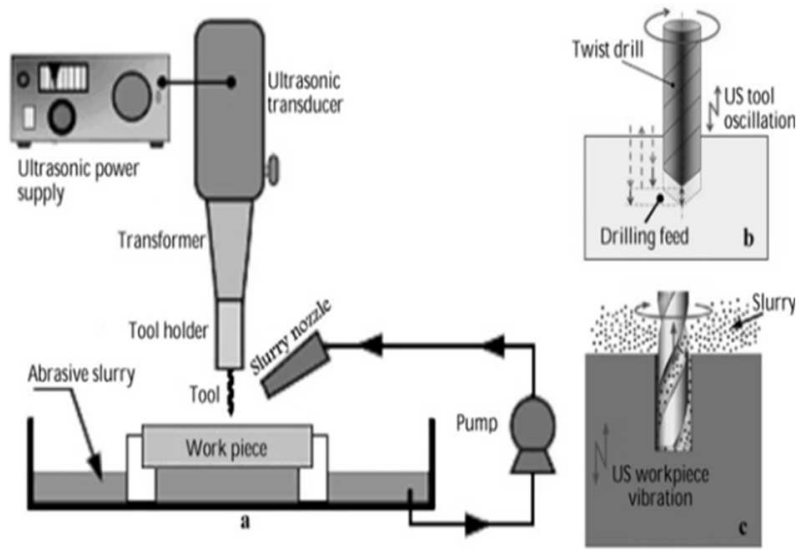

Fig. 5 Ultrasonic microdrilling

a) Setup of the machining process, b) tool oscilation a c) workpiece oscilation [20]

Figture 5 (b) is showing the tool oscilation when the workpieces is fixed in positon. Figture 5 (c) is showing the workpiece oscialtion where the tool is rotating in fixed axial position. [20]

Main disadvantage of the ultrasonic microdrilling is low speed of drilling process. Although the hole quality is much better in comparision to other technologies the slow process is limiting the use in praxis. [20]

Chemical engraving with use of sparks (SACE Spark assisted chemical engraving) that i salso sometimes called ECDM - electrochemical discharge machining and ECSM - electrochemical sparks machining are examples from many technologies of micromachining of glass and ceramics. This unconventional technology is based on electrochemical discharges. [21]

Mechanism of microdrilling with SACE is based on electrochemical discharge. The drilling itself is made with thermal etching. Two electrodes are used where the smaller electrode is the tool that machines the workpiece and the bigger on eis conter-electrode in the electrolytic solution created mostly with 30\% mass solution of $\mathrm{NaOH}$. [22,23]

Electrochemical discharges are present when the voltage is higher than the critical value that is depending of the geometry and concentration of used electrolyte. Typical values of critical voltage are around 30 $\mathrm{V}$. As soon as the critical voltage is reached first bubles are generated in the area of tool electrode. They start to grow rapidly and gather to create the gas film (layer) that isolates the tool electrode from electrolyte. Electrical field in this gas film is quite high (reguraly 106 $108 \mathrm{~V} / \mathrm{m}$ ), to allow the electrical discharges between the electrode of elektrolyte. Heat generated by these discharges and most probably some chemical etching are working together on eroding the workpiece. Workpiece must be placed in close distance from elektrode (less then $25 \mu \mathrm{m}$ for glass). [24]

Microdrilling to glass is dificult task and moreover in case of microdrilling with high sides ratio. The reason is the brittleness and non-conductive nature of glass. Traditional microdrilling takes realtivelly longer and archieves lower surface quality. On the other hand the thermal processes like laser microdrilling can provide higher output with respect speed of machining but there are often present problems in heat affected area and microcracks generation.

Procedures of chemical etching are also not suitable for microdrilling of glass because they are slow and difficult for making microholes with high depth-diameter ratio. Form this point of view the SACE technology that is based on etching using the heat provide a promising solution for microdrilling in brittle materials. Limitation of this technology is that is suitable mostly for brittle materials. 
Tab. 2 Comparision of individual technologies

Laser EDM

ECM

EBMD

SACE

Ultrasonic

Hole $\varnothing \quad[\mu \mathrm{m}]$ :

normally

$50-400$

$>100$

$>50$

5

8

80-200

$>300$

$100-500$

Min.

$$
1
$$

L-D ratio:

Normally

$$
10: 1
$$

600:1

10:1

Max.

$$
\text { 600:1 }
$$

$8: 1$

10:1

$5: 1$

10:1

250:1

$25: 1$

$8.8: 1$

Drilling speed $[\mathrm{mm} / \mathrm{s}]$ :

Normally
Max.
Surface
roughness:
Workpiece
material:

$<1$

6000

$<0.05$

0.1

18000

0,1

Chip removal: $\begin{aligned} & \text { Melting and } \\ & \text { evaporation }\end{aligned}$

Any diffi-

rough

moderately

rough

rough

Moderate rough

smoothest

Electricaly con-

Electricaly conductive

Any hard and ductive

brittle

Melting and

Metal

washing with di- disolving in electric

solution

Melting and evaporating

Advantage: High speed Drilling of com-
plex shapes

Better surface quality

High speed

Suitable for brittle material

Electricaly non-
conductive

Harder than

Melting and washing with electrolyte 40 HRC

Removal with suspension

Excellent surface quality

Better lubriSimple and flexible equipment cation between tool and workpiece

Poor qual- Lower control

Disadvantage: ity and of material re-

holes moval mecha-

Less precise

High initial in-

Suitable only for vestments brittle materials

Low speed

Cost of equpment and its maintenism

Not suita-

Rapid tool wear ble for / electrode costs complex shapes
Need of qualified operators nance

\section{Microdrilling}

In previous chapter the term microdrilling was defined. This chapter is about specifications, strategies and sequence of operation steps. At the beginning it is need to define cutting tools that are necessary for this technolgy.

Microdrilling bits often break before they get worn. Therefore, the tool life of these bits is quite unpredictable. It is caused by quite big load against its 
strength. Therefore it is important to choose wisely the drill bit tool material, the cutting geometry, construction, cooling liquid, clamping and cutting conditions. These parameters influence the ability to maintain ideal conditions for microdrilling. Even a negligible change of parameters can lead to destruction of these delicate tools.

Microdrill bit geometry significantly influence the way how the microdrilling bit operates. According to differences in cross-section profiles the drill bits are ordered in three groups. First groups with diameter from $0.5 \mathrm{~mm}<\mathrm{d}<1 \mathrm{~mm}$ has similar shape as normal drill bits. In second group with diameters from 0.2 $\mathrm{mm}<\mathrm{d}<0.5 \mathrm{~mm}$ the drill bits have the same diameter on whole surface. In third groups belong all drill bits with diameter $\mathrm{d}<0.2 \mathrm{~mm}$ with reduced shank. According the manufacturers is best choice to use drill bits with point angle value in range from $120^{\circ}$ to $130^{\circ}$ for harder workpiece materials and around $90^{\circ}$ for softer materials. Another important factor is the helix angle that is usually $30^{\circ}$. Another issue is the friction that should be the lowest possible not to increase the temperature. Flutes (grooves) are quite tiny that causes bad flow of chips and thus higher probability of temperature increase. Another important factor is also the length of helix because with increasing length the drill bit rigidity lowers.

A lot of different microdrill bits types are available in the market. Mostly often are used spiral drill bits, spade drill bits and D shaped drill bits. Most complex but also most suitable shape of cutting part has the spiral drill bit that is also most demanded on market. Spade drill bit and $\mathrm{D}$ shaped drill bit are in comparison much simpler and easier to manufacture. They have limited cutting properties and therefore they are rarely used.

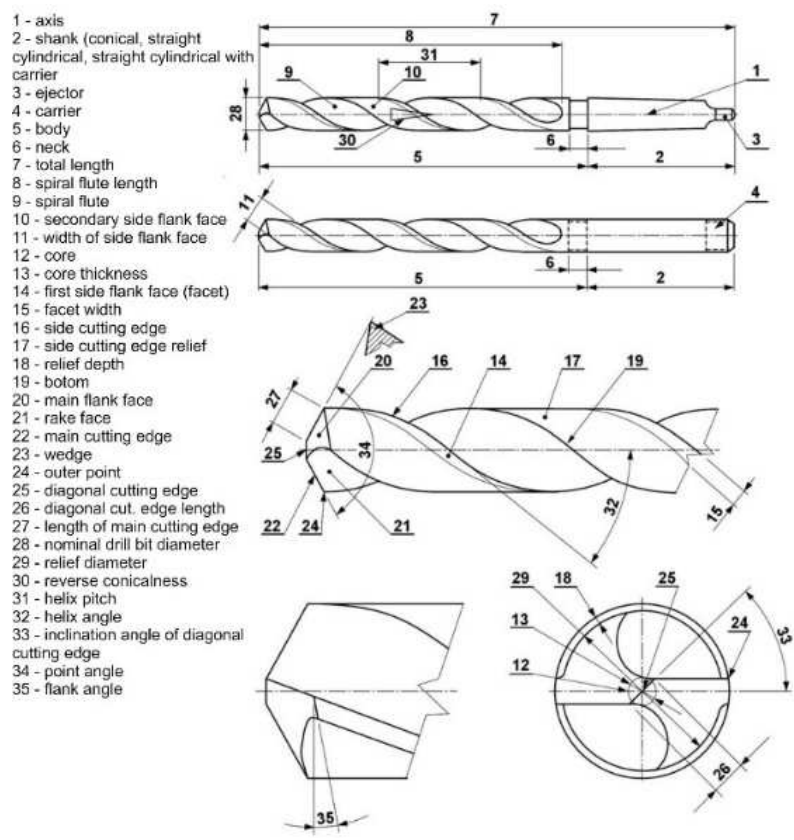

Fig. 6 Tool features description [25]

\section{Optomechanical parts - fiber arrays}

Fiber arrays are made for very accurate positioning of optical fibers in a row (1D) or in a plane (2D). Fiber arrays may be made with most types of fibers including polarization maintaining (PM) fibers. Fibers end faces at fiber arrays may be polished at different angles according their application. The thickness of cover glass at $1 \mathrm{D}$ fiber arrays may be thinned up to $150 \mu \mathrm{m}$ and the end faces can be covered with reflex or antireflex layers as well as by lens array. 2D fiber arrays can be housed in metal flanges and the other side of fibers may be terminated by optical connectors.

Fiber arrays are made of glass. Into sanded/polished glass discs are pulse lasered precise holes into with are subsequently sealed optical fibers in various patterns. Then the front face of the whole array is sanded/polished and coated with anti-reflex layer according the demand. Fiber arrays are most often made of quartz, borosilicate glass or $\mathrm{Al}_{2} \mathrm{O}_{3}$. Fiber arrays can be according the specification placed into aluminum (anodized) respectively stainless-steel holders for subsequent attachment in given application. On assembled matrix array distances between the actual and the ideal position of fiber holes are measured. [26]

\section{Conclusion}

The article analyzes in detail and describes possible technologies of small holes manufacturing. These technologies are considered for use in optomechanical parts manufacturing particularly of fiber arrays. Optomechanical parts have the prescribed high accuracy and are also subject to high requirements in terms of surface quality. It is often the case that there is a prescription for SPI A1 quality in the production documentation. It is a prescription according to the standard used in the plastics industry and for the field of mechanical engineering it is defined as a super highgloss surface. The corresponding parameter $\mathrm{Ra}=$ $0.012-0.025 \mu \mathrm{m}$ is given in roughness units. Dimensions are usually prescribed with a thousandth specification.Currently based on table Tab.2 that the microdrilling is the most suitable technology. As noticed in chapter 2 most used tool are spiral drill bits. Spiral drill bit is a tool designed for making holes in material. Most often we can encounter double edged drill bits with two opposite helical flutes for chip removal. Helical grooved body allows also effective cooling. Helix angle against the tool axis is selected according drilled material and is in the range from $10^{\circ}$ to $45^{\circ}$. Geometry of the tool cutting edge is very important and affects the size of cutting forces, quality of machined surface and the tool life of the cutting edge itself. Future research in the field of microholes drilling will focus on use of other types of microdrilling bits on geometry of tool and use of tool materials with high precision and machined surface quality. 


\section{References}

[1] HORKÝ, V. (2019). Nástroje pro mikrovrtání [online]. Praha, 2019 [quoted 2019-11-29]. Available at: https://dspace.cvut.cz/bitstream/handle/10467/84907/F2-BP-2019Horky-Vaclav-Nastroje \%20pro\%20mikrovrtani.pdf?sequence $=-1$ \&isAllowed $=\mathrm{y} . \quad$ Bachelor thesis. CTU, Faculty of mechanical engineering, Praha. Thesis tutor Ing. BcA. Jan Podaný, Ph.D.

[2] KAPOOR, S., Journal of manufacturing processes [online]. Dearborn, Mich.: Society of Manufacturing Engineers, 1999- [quoted 2019-06-30]. ISBN 1526-6125

[3] LASCAM. Lascam [online]. [quoted 2019-1129]. Available at: https://www.lascam.cz/lasery-pro-vrtani/

[4] BUREŠ, M. (2019). Využití laserového mikroobrábění pro úpravu povrchu 3D tištěných kovových dílů [online]. Plzeň, 2018 [quoted 2019-11-29]. Available at: https://otik.uk.zcu.cz/bitstream/11025/33064/4/BP_v11_rev_.pdf?fb clid=IwAR1Fd0Kbh_hyn0Xoq6tR9m2ryYN6711ZqKUW2-

A3hU8cyZwlyfarzp3mlE. Bachelor thesis. University of West bohemia in Pilsen. Thesis tutor Doc. Ing. Miroslav Zetek, Ph.D.

[5] Lasery a Optika. Lao [online]. [quoted 2019-1129]. Available at: http://www.lao.cz/lao-info49/vyuziti-laseru-v-prumyslu--minulost-a-soucasnost-313

[6] LASCAM. Lascam [online]. [quoted 2019-1129]. Available at: https://www.lascam.cz

[7] D'URSO, G., Process performance of micro-EDM drilling of stainless steel [online]. 2014 [quoted 2019-11-29]. Available at: https:/ /link.springer.com/article/10.1007\%2Fs00170-014-5739-1

[8] D'URSO, G., A model to predict manufacturing cost for micro-EDM drilling [online]. 2017 [quoted 2019-11-29]. Available at: https://link.springer.com/content/pdf/10.1007\%2Fs00170-016-9950-0.pdf1

[9] ELUC. Elektronická uáebnice: Obrábèní elektronoyym paprskem [online]. [quoted 2019-1129]. Available at: https://eluc.kr-olomoucky.cz/verejne/lekce/1421

[10] MMSpektrum: Nekonvenční metody obrábèni - 6. díl [online]. 2008 [quoted 2019-11-29]. Availa- ble at: https://www.mmspektrum.com/clanek/nekonvencni-metody-obrabeni-2.html

[11] MATLÁK, J., (2013) Povrchové zpracování vybraných ocelí pomocí elektronového svazku [online]. Brno, 2013 [quoted 2019-1129]. Available at: https://dspace.vutbr.cz/xmlui/bitstream/handle/11012/24851/2013_DP_Matlak_Jiri_115 841. pdf?sequence $=1$ \&isAllowed=y. Master thesis. BUT Brno. Thesis tutor Ing. Miloslav Kouřil, CSc.

[12] ORÍŠEK, P., (2016) Povrchové zpracování vybraných ocelí pomocí elektronového svazku [online]. Brno, 2016 [quoted 2019-1129]. Available at: https://www.vutbr.cz/www_base/zav_prace_ soubor_verejne.php?file_id=129199. Master thesis. BUT Brno. Thesis tutor Ing. Miloslav Kourili, CSc.

[13] MMSpektrum: Nekonvenčni metody obrábèní [online]. 2007 [quoted 2019-11-29]. Available at: https://www.mmspek-

trum.com/clanek/nekonvencni-metody-obrabeni-2-2.html

[14] Slideplayer: Fyzikálni metody obrábèní[online]. 2013 [quoted 2019-11-29]. Available at: https://slideplayer.cz/slide/3638931/

[15] DEBNATH, K., SINGH, I., \& DVIVEDI, A. (2015). Rotary mode ultrasonic drilling of glass fiber-reinforced epoxy laminates. Journal of Composite Materials, 49(8), 949-963. https://doi.org/10.1177/0021998314527857

[16] NATH, CH., LIM, G.C.., ZHENG, H.Y., (2012) Influence of the material removal mechanisms on hole integrity in ultrasonic machining of structural ceramics, Ultrasonics, Volume 52, Issue 5, 2012, Pages 605613, https://doi.org/10.1016/j.ultras.2011.12. 007.

[17] THOE, T.B., ASPINWALL, D.K., WISE, M.L.H., Review on ultrasonic machining (1998) International Journal of Macbine Tools and Manufacture, 38 (1998), pp. 239-255

[18] ICHIDA, Y., SATO, R., MORIMOTO, Y., KOBAYASHI, K. (2005). Material removal mechanisms in non-contact ultrasonic abrasive machining, Wear, 258 (2005), pp. 107-114

[19] KOMARAIAH, M., REDDY, P.N. (1993). A study on the influence of workpiece properties in ultrasonic machining, International Journal of 
Macbine Tools and Manufacture, 33 (1993), pp. 495-505

[20] MAHADI, H., ZHAO, J., JIANG, Z. (2017). A review of modern advancements in micro drilling techniques, Journal of Manufacturing Processes, Volume 29, 2017, Pages 343375, https://doi.org/10.1016/j.jmapro.2017.0 8.006 .

[21] WÜTHRICH, R., FASCIOM V., (2005) Machining of non-conductive materials using electrochemical discharge phenomenon-an overview International Journal of Machine Tools and Manufacture, 45 (2005), pp. 1095-1108 https://doi.org/10.1016/j.ijmachtools.2004.11 .011

[22] JANA, D., ZIKI, A,, WÜTHRICH, R.. (2013). Forces exerted on the tool-electrode during constant-feed glass micro-drilling by spark assisted chemical engraving, International Journal of Macbine Tools and Manufacture, Volume 73, 2013, Pages

47-54, https://doi.org/10.1016/j.ijmachtools.2013.06 .008 .

[23] MAHADI, H., ZHAO, J., JIANG, Z. (2017). A review of modern advancements in micro drilling techniques, Journal of Manufacturing Processes, Volume 29, 2017, Pages 343-375, https://doi.org/10.1016/j.jmapro.2017.08.006.
[24] WÜTHRICH, R., SPAELTER, U.; WU, Y., BLEULER, H. (2006). A systematic characterization method for gravity-feed micro-hole drilling in glass with spark assisted chemical engraving (SACE) Published 4 August 2006 Publishing Ltd Journal of Micromechanics and Microengineering, Volume 16, Number 9 https://doi.org/10.1088/09601317/16/9/019

[25] HUMAR, A. (2004) Technologie I, Technologie obrábèni - 2.část, p.9, BUT Brno, Brno, [quoted 2019-11-29]. Available at: http://ust.fme.vutbr.cz/obrabeni/oporysave/TI_TO-2cast.pdf

[26] SQS - vláknová pole [online]. [quoted 2019-1129]. Available at: https://www.sqs-fiberoptics.com/cs/produkty/vlaknova-pole

[27] KUBIŠOVÁ, M., PATA, V., SÝKOROVÁ, L., MALACHOVÁ, M. (2017). Use of cluster analysis for assessment of surface replicas machined by a laser beam, Manufacturing Technology, vol. 17, pp. 489 - 493, 2017. ISSN 1213-2489.

[28] KUBIŠOVÁ, M.; PATA, V.; SÝKOROVÁ, L.; KNEDLOVÁ, J. (2017). Influence of laser beam on polymer material, Manufacturing Technology, vol. 17, pp. 742 - 746, 2017. ISSN 12132489. 